\title{
Biosorption of heavy metal ions on peel of Artocarpus nobilis fruit: 1 - Ni(II) sorption under static and dynamic conditions
}

\author{
Namal Priyantha ${ }^{1,2} \cdot$ P. A. Kotabewatta ${ }^{1,2}$
}

Received: 14 June 2018 / Accepted: 11 February 2019 / Published online: 9 March 2019

(c) The Author(s) 2019

\begin{abstract}
The peel of the edible fruit, Artocarpus nobilis, a plant endemic to Sri Lanka, shows remarkable adsorption capabilities toward $\mathrm{Ni}(\mathrm{II})$, a heavy metal ion. Removal efficiency of $50 \%$ obtained with air-dried particles $(0.710 \mathrm{~mm}<d<1.0 \mathrm{~mm})$ of the above waste material under both static and dynamic conditions. It is enhanced to $71 \%$ after optimization of shaking time, settling time and processed temperature within a solution $\mathrm{pH}$ range of 4.0-7.0. Application of data on linearized Langmuir isotherm model shows a higher regression coefficient of 0.994, as compared to that of the Freundlich model, leading to the maximum adsorption capacity of $12,048 \mathrm{mg} \mathrm{kg}^{-1}$. The amount of biosorption of $\mathrm{Ni}(\mathrm{II})$ at equilibrium determined from the pseudo-first-order model is $2259 \mathrm{mg} \mathrm{kg}^{-1}$ which is in good agreement with the experimental value of $2348 \mathrm{mg} \mathrm{kg}^{-1}$. Removal efficiency further increases under dynamic conditions up to $93 \%$ by optimizing the packing bed height and flow rate. Application of dynamic adsorption models, namely Thomas, Adams-Bohart and Yoon-Nelson, shows attractive results with high regression coefficients. It is conclusively demonstrated that the peel of Artocarpus nobilis fruit can be used as an effective biosorbent for the removal of $\mathrm{Ni}(\mathrm{II})$ from wastewater.
\end{abstract}

Keywords Artocarpus nobilis · Biosorbent · Parameter optimization · Thomas model · Adams-Bohart model · YoonNelson model

\section{Introduction}

Expansion of industrial activities over the past few decades has contributed to increased levels of metallic constituents in the aquatic environment (Qaiser et al. 2009). Bivalent metal ions, such as $\mathrm{Cu}(\mathrm{II}), \mathrm{Ni}(\mathrm{II})$ and $\mathrm{Cd}(\mathrm{II})$, and their compounds commonly found in industrial wastewater would accumulate in fish and other aquatic organisms. These metal ions are transferred to higher animals through food chain by bioaccumulation, bioconcentration and biomagnification (Hossain et al. 2014).

The presence of excess $\mathrm{Ni}$ (II) ions in the environment, particularly in water, would cause various types of acute and chronic disorders, such as damage to lungs and kidneys, gastrointestinal distress, pulmonary fibrosis and skin dermatitis (Borba et al. 2006). Therefore, removal of Ni(II)

Namal Priyantha

namal.priyantha@yahoo.com

1 Postgraduate Institute of Science, University of Peradeniya, Peradeniya, Sri Lanka

2 Department of Chemistry, University of Peradeniya, Peradeniya, Sri Lanka from industrial wastewater is a necessity to safeguard the quality of life in the ecosystem. In this regard, various techniques are applied for the treatment of heavy metals, including chemical precipitation, coagulation/flocculation, ion exchange, electrochemical processes and membrane technology (Amuda and Ibrahim 2006).

Chemical methods are found to be neither economical nor environmentally friendly, as compared to biosorption processes (Ali 2013). On the other hand, plant-based materials, such as orange peel (Feng et al. 2011), peanut shell (Krowiak et al. 2011), Cassia fistula biomass (Hanif et al. 2007), Ficus religiosa leaves (Qaiser et al. 2009), Artocarpus camansi Blanco (breadnut) (Lim et al. 2016), Artocarpus altilis (Lim et al. 2015), dragon fruit skin (Priyantha et al. 2013) and Artocarpus odoratissimus (Tarap) (Lim et al. 2013), have shown remarkable biosorption abilities. In addition to being effective and economical for treatment of wastewater having low heavy metal ion concentrations, regeneration would not be necessary for biosorption due to ready availability of such materials.

Biosorption of metal ions can help to design kinetic models and to select the optimum operating conditions in fullscale batch process. The kinetic behavior of metal ion can 
be investigated using pseudo-first-order and pseudo-secondorder models, as mentioned below (Rashid et al. 2016),

$\log \left(q_{\mathrm{e}}-q_{\mathrm{t}}\right)=-\frac{k_{1}}{2.303} t+\log \left(q_{\mathrm{e}}\right)$

where $q_{\mathrm{e}}$ and $q_{\mathrm{t}}$ are the sorption capacity $\left(\mathrm{mg} \mathrm{kg}^{-1}\right)$ at equilibrium and at time $t$, and $k_{1}$ is the rate constant of pseudofirst-order sorption $\left(\mathrm{min}^{-1}\right)$.

$\frac{t}{q_{\mathrm{t}}}=\frac{1}{q_{\mathrm{e}}} t+\frac{1}{k^{\prime} q_{\mathrm{e}}^{2}}$

where $k^{\prime}$ is the rate constant of pseudo-second-order sorption $\left(\mathrm{kg} \mathrm{mg}^{-1} \mathrm{~min}^{-1}\right)$.

Adsorption equilibrium data describe the relationship between the mass of adsorbate adsorbed per unit mass of adsorbent, and adsorption isotherms represent the liquidphase equilibrium concentration of adsorbates (Belhachemi and Addoun 2011). Two-parameter adsorption models (Langmuir, Tempkin and Freundlich) and three-parameter adsorption models (Redlich-Peterson and Sips) are the most common models which provide valuable data for designing adsorption systems (Tosun 2012). A commonly used linearized Langmuir isotherm relationship is given by (Shahmohammadi-Kalalagh and Babazadeh 2014),

$\frac{C_{\mathrm{e}}}{q_{\mathrm{e}}}=\frac{1}{q_{\max } b}+\frac{C_{\mathrm{e}}}{q_{\max }}$

where $q_{\max }$ is the maximum monolayer capacity of biosorbent $\left(\mathrm{mg} \mathrm{kg}^{-1}\right), b$ is the isotherm constant $\left(\mathrm{L} \mathrm{mg}^{-1}\right), C_{\mathrm{e}}$ is the equilibrium concentration of adsorbate $\left(\mathrm{mg} \mathrm{L}^{-1}\right)$ and $q_{\mathrm{e}}$ is the mass adsorbed per unit mass of adsorbent $\left(\mathrm{mg} \mathrm{kg}^{-1}\right)$.

The linearized Freundlich equation is expressed as (Olalekan et al. 2013),

$\ln q_{\mathrm{e}}=\ln k_{\mathrm{f}}+\frac{1}{n} \ln C_{\mathrm{e}}$

where $k_{\mathrm{f}}$ is the Freundlich constant $\left(\mathrm{mg} \mathrm{kg}^{-1}\right)$ and $n$ is adsorption intensity.

The Thomas model has been derived using the assumptions of Langmuir kinetics of adsorption-desorption and no axial dispersion. It obeys the second-order reversible reaction kinetics (Tamilselvi and Asaithambi 2015). The Thomas model is given as (Chu 2010),

$\ln \left(\frac{C_{\mathrm{o}}}{C_{\mathrm{t}}}-1\right)=\frac{k_{\mathrm{Th}} q_{\mathrm{o}} w}{v}-k_{\mathrm{Th}} C_{\mathrm{o}} t$

where $k_{\mathrm{Th}}$ is the Thomas rate constant $\left(\mathrm{mL} \mathrm{min}^{-1} \mathrm{mg}^{-1}\right)$, $C_{\mathrm{o}}$ and $C_{\mathrm{t}}$ are the inlet and outlet adsorbate concentrations $\left(\mathrm{mg} \mathrm{L}^{-1}\right), q_{\mathrm{o}}$ is the sorption capacity of the adsorbent per unit mass of the adsorbent $\left(\mathrm{mg} \mathrm{g}^{-1}\right), w$ is the mass of adsorbent $(\mathrm{g}), v$ is the flow rate $\left(\mathrm{mL} \mathrm{min}{ }^{-1}\right)$ and $t$ is the time of measurement ( $\mathrm{min})$.
The Adams-Bohart model is applied to sorption data in order to describe the breakthrough curve. This model is used for the description of the initial part of the breakthrough curve (Salamatinia et al. 2008). It is given as (Baral et al. 2009),

$\ln \frac{C_{\mathrm{t}}}{C_{\mathrm{o}}}=k_{\mathrm{AB}} C_{\mathrm{o}} t-k_{\mathrm{AB}} N_{\mathrm{o}} \frac{Z}{F}$

where $k_{\mathrm{AB}}$ is the mass transfer coefficient $\left(\mathrm{L} \mathrm{mg}^{-1} \mathrm{~min}^{-1}\right), N_{\mathrm{o}}$ is the saturation concentration $\left(\mathrm{mg} \mathrm{L}^{-1}\right), Z$ is the bed height $(\mathrm{cm})$ and $F$ is the linear flow rate $\left(\mathrm{cm} \mathrm{min}^{-1}\right)$.

The Yoon-Nelson model is derived based on the assumption that the rate of decrease in the probability of adsorption for each adsorbate molecule is proportional to the probability of adsorption of adsorbate and the probability of adsorbate breakthrough on the adsorbent (Ayoob and Gupta 2007). It is given as (Aziz et al. 2014),

$\ln \frac{C_{0}}{C_{0}-C_{\mathrm{t}}}=k_{\mathrm{YN}} t-\tau k_{\mathrm{YN}}$

where $k_{\mathrm{YN}}$ is the rate constant $\left(\mathrm{min}^{-1}\right)$ and $\tau$ is the time required for $50 \%$ adsorbate breakthrough ( $\mathrm{min}$ ).

Cellulose, hemicellulose and lignin are structural organic substances present in plant-based materials (McKendry 2002). These substances comprise many functional groups, such as carbonyl, phenolic, carboxyl, alcohol and ester (Sud et al. 2008). Plant-based materials therefore show a strong affinity to biosorb heavy metals. The swelling effect of particles can happen by adsorption of large amount of water, thereby increasing the volume-to-area ratio, which eventually enhances the biosorption process (Demirbas 2008). Breadfruit plants (Artocarpus species) are rich in phenolic compounds including flavonoids, stilbenoids and arylbenzofurons (Abu Bakar et al. 2009; Jagtap and Bapat 2010). The formation of negative ions by losing $\mathrm{H}^{+}$from the hydroxyl group of phenols helps to attract cations (Al-Asheh et al. 2000). The present study was carried out using the fruit peel of Artocarpus nobilis, which is a waste material. Artocarpus nobilis plant, a variety of breadfruit, is endemic to Sri Lanka and restricted to lowland rain forests. The objective of this research is to investigate the ability of the peel of the fruit of Artocarpus nobilis for biosorption of $\mathrm{Ni}$ (II) from synthetic solutions through the application of static and dynamic adsorption models, and to investigate the suitability of using this low-cost adsorbent for the removal of $\mathrm{Ni}(\mathrm{II})$ from contaminated solutions.

\section{Materials and methods}

\section{Materials}

The peel of Artocarpus nobilis fruits was removed, airdried and stored until biosorption experiments were 
conducted. Resulting dried samples were blended and sieved to obtain particle sizes in the range of $0.710 \mathrm{~mm}<d<1.0 \mathrm{~mm}$. The stock solutions of $\mathrm{Ni}(\mathrm{II})$ were prepared using analytical grade $\mathrm{NiSO}_{4}$ dissolved in deionized water. Solution $\mathrm{pH}$ was adjusted as needed using analytical grade $\mathrm{NaOH}$ and/or $\mathrm{HNO}_{3}$.

\section{Characterization of biosorbent}

Air-dried fruit peel of Artocarpus nobilis was crushed into fine powder and mixed with dried $\mathrm{KBr}$ in a ratio of 1:100, and Fourier transform infrared (FTIR) spectra were recorded for the pellets prepared.

Unprocessed peel $(1.25 \mathrm{~g})$ was stirred with $0.25 \mathrm{~L}$ of $0.10 \mathrm{~mol} \mathrm{~L}^{-1} \mathrm{NaNO}_{3}$ solution. The $\mathrm{pH}$ of the peel suspension was adjusted to 4.0 by adding $\mathrm{HNO}_{3}$ acid $\left(0.138 \mathrm{~mol} \mathrm{~L}^{-1}\right.$, as standardized with primary standard $\mathrm{Na}_{2} \mathrm{CO}_{3}$ solution of $0.100 \mathrm{~mol} \mathrm{~L}^{-1}$ ). Then, the $\mathrm{pH}$ was raised up to 10.0 by adding small volumes of $\mathrm{NaOH}$ solution of $0.0990 \mathrm{~mol} \mathrm{~L}^{-1}$ as standardized with the secondary standard $\mathrm{HNO}_{3}$ acid solution, and the $\mathrm{pH}$ after each addition was recorded. This experiment was repeated for $0.010 \mathrm{~mol} \mathrm{~L}^{-1}$ and $0.0010 \mathrm{~mol} \mathrm{~L}^{-1} \mathrm{NaNO}_{3}$ solutions. Thereafter, the surface charge density was calculated and plotted against $\mathrm{pH}$ of the solution in order to determine the point of zero charge.

\section{Optimization of experimental parameters}

A series of solutions containing $0.100 \mathrm{~g}$ of each peel and $50.0 \mathrm{~mL}$ of $10.0 \mathrm{mg} \mathrm{L}^{-1} \mathrm{Ni}(\mathrm{II})$ solution was shaken at a speed of $150 \mathrm{rpm}$. Remaining $\mathrm{Ni}(\mathrm{II})$ concentration in each solution was determined immediately, using SpectroElectronic M Series atomic absorption spectrophotometer (AAS) at ambient temperature of $27 \pm 1^{\circ} \mathrm{C}$. These solutions were shaken for the optimum time period. Thereafter, each solution was allowed to stand for different settling times, and the remaining $\mathrm{Ni}(\mathrm{II})$ content was determined.

The same solutions $\left[50.0 \mathrm{~mL}\right.$ of $10.0 \mathrm{mg} \mathrm{L}^{-1} \mathrm{Ni}(\mathrm{II})$ solution with $0.100 \mathrm{~g}$ peel] were used to optimize the time period of thermal treatment of the biosorbent at a constant temperature of $125^{\circ} \mathrm{C}$ in an oven, and the remaining $\mathrm{Ni}$ (II) concentrations were determined. Then, the treatment temperature was optimized using the optimized treatment time at different temperatures using the same oven under other optimized conditions.

The effect of $\mathrm{pH}$ on the extent of removal of $\mathrm{Ni}(\mathrm{II})$ was determined at different initial solution $\mathrm{pH}$ values maintained using $0.1 \mathrm{~mol} \mathrm{~L}^{-1} \mathrm{NaOH}$ and conc. $\mathrm{HNO}_{3}$.

All experiments were performed in triplicate, and average values were reported.

\section{Adsorption isotherms}

Amount of biosorption of $\mathrm{Ni}(\mathrm{II})$ by peel was determined in each solution $(50.0 \mathrm{~mL}$ solution with $0.100 \mathrm{~g}$ peel) of concentrations changing from 10.0 to $1000.0 \mathrm{mg} \mathrm{L}^{-1}$. The relationship between the extent of biosorption and equilibrium concentration of $\mathrm{Ni}$ (II) was studied in order to check the validity of adsorption isotherm models, such as Langmuir and Freundlich.

\section{Adsorption kinetics}

The extent of removal of $\mathrm{Ni}(\mathrm{II})$ by $2.000 \mathrm{~g}$ of fruit peels at different contact times was investigated using $1.0 \mathrm{~L}$ of $10.0 \mathrm{mg} \mathrm{L}^{-1}$ of $\mathrm{Ni}(\mathrm{II})$ ion solution until equilibrium was reached. Results were analyzed to check the validity of different kinetics models.

\section{Dynamic experiments}

Pyrex glass tubes of $1.0 \mathrm{~cm}$ internal diameter packed up to a constant bed height of $10.0 \mathrm{~cm}$ were used to investigate dynamic biosorption of $\mathrm{Ni}$ (II) on the biosorbent. Synthetic $\mathrm{Ni}$ (II) solution of $10.0 \mathrm{mg} \mathrm{L}^{-1}$ was fed to the column filled with the biosorbent, and eluent samples were collected at different flow rates at 5-min time intervals. The remaining $\mathrm{Ni}(\mathrm{II})$ concentrations were determined for the optimization of flow rate. Then, bed height was optimized in the same manner by changing different packing bed heights from 2.5 to $10.0 \mathrm{~cm}$. In addition, the mass of $3.0 \mathrm{~g}$ is sufficient to fill the bed height of $10.0 \mathrm{~cm}$.

\section{Results and discussion}

\section{Characterization of the adsorbent}

The FTIR spectrum of raw peel, given in Fig. 1, shows sharp and broad absorption peaks representing the functional

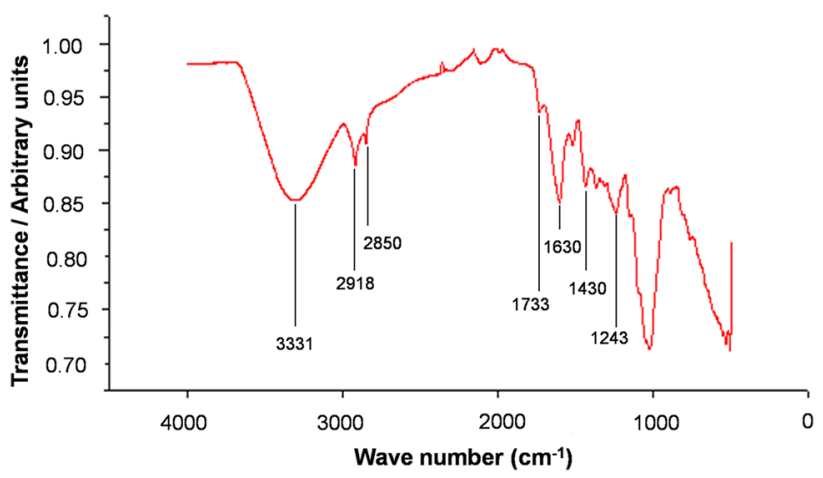

Fig. 1 FTIR spectrum of Artocarpus nobilis fruit peel

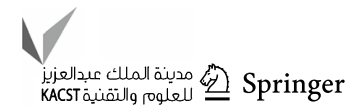


Table 1 Active functional groups present in the peel of Artocarpus nobilis fruit

\begin{tabular}{lll}
\hline Bond type & Wave number $\left(\mathrm{cm}^{-1}\right)$ & Available compounds \\
\hline $\mathrm{C}-\mathrm{O}$ & 1243 & Alcohol, ether, carboxylic acid, ester, acid anhydride \\
$\mathrm{C}=\mathrm{O}$ & 1733 & Aldehyde, ester, carboxylic acid \\
$\mathrm{O}-\mathrm{H}$ & 2850 & Carboxylic acid (Hydrogen bonded) alcohol, phenol \\
& 2918 & \\
& 3331 & \\
\hline
\end{tabular}

groups listed in Table 1. The bands at 1243, 1733 and $2850 \mathrm{~cm}^{-1}$ indicate the presence of carboxylic acid derivatives which are very important for complexation with heavy metal ions. The presence of similar bands has been reported for many natural adsorbents, such as breadfruit peel, mango peel and banana peel (Lim et al. 2015; Iqbal et al. 2009; Castro et al. 2011).

\section{Zero point charge of adsorbent}

Surface charge of the peel of Artocarpus nobilis fruit is negative, which becomes more negative as the medium $\mathrm{pH}$ increases according to the surface charge determined as a

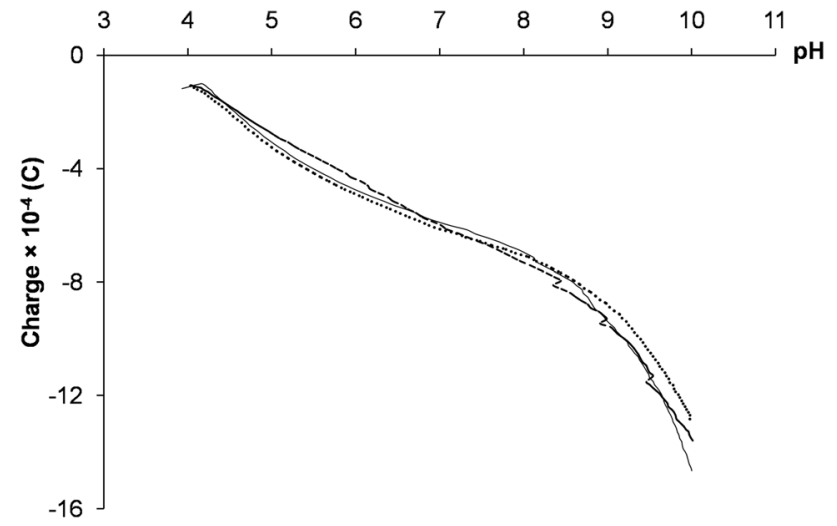

Fig. 2 Surface titration curve of the peel of Artocarpus nobilis fruit suspension, plotted as variation of surface charge with $\mathrm{pH}$ controlled by additions of $\mathrm{NaOH}$ at ambient temperature in $\mathrm{NaNO}_{3}$ solutions of different concentrations. $0.1 \mathrm{M}$ (solid line) $0.01 \mathrm{M}$ (dotted line) $0.001 \mathrm{M}$ (dashed line)

Table 2 Optimum contact time for removal of $\mathrm{Ni}(\mathrm{II})$ for different biosorbents function of $\mathrm{pH}$ for different ionic strengths, as shown in Fig. 2. The point of zero charge is estimated in the $\mathrm{pH}$ range of 3.0-4.5 based on the variation of the surface charge with $\mathrm{pH}$. The background electrolyte, $\mathrm{NaNO}_{3}$, is commonly used for surface titrations, as its constituent ions do not specifically bind to the biosorbent surface. Hence, it is assumed that no ion other than protons in the medium binds to the biosorbent during surface titrations. As the natural $\mathrm{pH}$ of the Artocarpus nobilis fruit peel is 5.9, adsorption occurs favorably under ambient conditions.

\section{Optimization of experimental parameters}

The extent of removal of $\mathrm{Ni}(\mathrm{II})$, determined using $10.0 \mathrm{mg} \mathrm{L}^{-1}$ solution at zero settling time, was increased within the first 100 min of shaking and then becomes constant. Therefore, the optimum shaking time of interaction of $\mathrm{Ni}$ (II) with the peel of Artocarpus nobilis fruit was considered as $120 \mathrm{~min}$, at which $45 \%$ removal was obtained. The optimum contact time for removal of $\mathrm{Ni}$ (II) varies with different biosorbents as stated in Table 2. As the ionic radius of $\mathrm{Ni}$ (II) is comparatively low, it forms an octahedral structure combining with six $\mathrm{H}_{2} \mathrm{O}$ molecules when in contact with water, resulting in a large hydrated radius (Persson 2010). Therefore, more time is required to reach the equilibrium state of the biosorption process together with relatively low removal percentage.

Thereafter, settling time was optimized for the most efficient removal for $\mathrm{Ni}$ (II) by the peel. According to the results, the extent of removal of $\mathrm{Ni}$ (II) was almost constant from the beginning with small fluctuations. Therefore, the optimum settling time was selected as 30 min at which $50 \%$ removal was obtained.

\begin{tabular}{lll}
\hline Adsorbents & $\begin{array}{l}\text { Optimum contact time } \\
(\mathrm{min})\end{array}$ & References \\
\hline Punica granatum peel & 600 & Bhatnagar and Minocha (2010) \\
Citrus reticulata peel & 60 & Pavan et al. (2006) \\
Sugarcane Bagasse & 120 & Alomá et al. (2012) \\
Moringa oleifera leaf powder & 50 & Reddy et al. (2012) \\
Protonated rice bran & 240 & Zafar et al. (2007) \\
Enteromorpha prolifera (green algae) & 120 & Özer et al. (2008) \\
Olive stone waste & 60 & Fiol et al. (2006) \\
Mucor hiemalis (fungal biomass) & $210-255$ & Shroff and Vaidya (2011) \\
\hline
\end{tabular}


The effect of the initial solution $\mathrm{pH}$ on $\mathrm{Ni}$ (II) removal was studied at different $\mathrm{pH}$ values ranging from 1.0 to 7.0 at optimized shaking and settling times (Fig. 3). Solution $\mathrm{pH}$, which affects the chemical composition and the surface charge of the biosorbent, is an important parameter in biosorption. According to Fig. 3, the extent of removal of $\mathrm{Ni}(\mathrm{II})$ is increased with an increase in $\mathrm{pH}$ up to 4 . Low removal percentages of $\mathrm{Ni}$ (II) at low $\mathrm{pH}$ is probably due to the presence of high concentrations of $\mathrm{H}_{3} \mathrm{O}^{+}$, which can easily compete with hydrated $\mathrm{Ni}(\mathrm{II})$ for adsorption sites. Therefore, $\mathrm{Ni}(\mathrm{II})$ adsorption decreases due to repulsion of $\mathrm{H}_{3} \mathrm{O}^{+}$. Beyond $\mathrm{pH} 4$, removal efficiency was almost constant up to $\mathrm{pH}$ 7.0. However, acidic $\mathrm{pH}$ of 5.9 is shown by aqueous suspensions of peel under ambient condition due to the carboxyl and hydroxyl groups present in the biosorbent.

Treatment temperature of $125^{\circ} \mathrm{C}$ employed for processing the biosorbent would cause the removal of moisture, exposing pores for adsorption. A sufficient period of thermal treatment is thus important to effectively remove the moisture content. The effect of thermal treatment time on

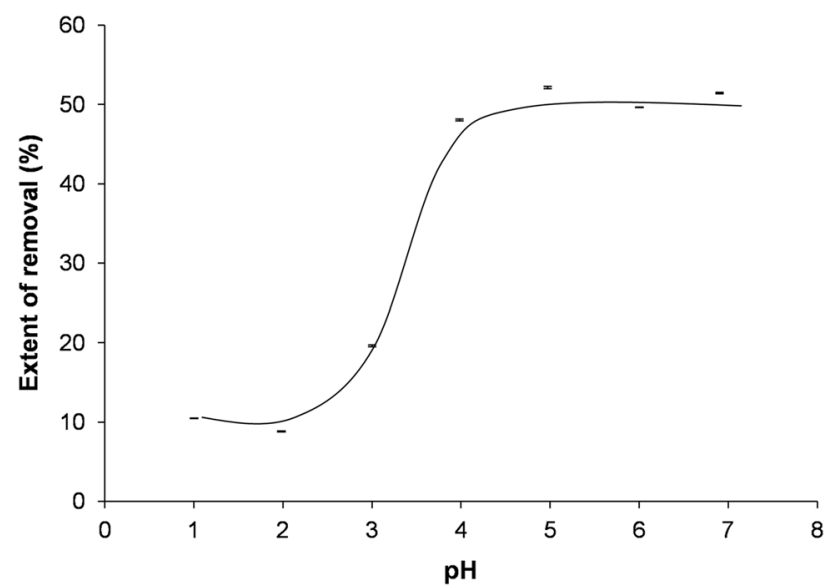

Fig. 3 Variation of extent of removal of $\mathrm{Ni}(\mathrm{II})$ at different $\mathrm{pH}$ $\left(0.100 \mathrm{~g} \mathrm{peel,} 10.0 \mathrm{mg} \mathrm{L}^{-1}\right.$ of $50.0 \mathrm{~mL}$ solution, $120 \mathrm{~min}$ shaking time, 30 min settling time) the extent of removal of $\mathrm{Ni}$ (II) shows the expected marginal increase (Fig. 4a). After 90 min of heating, no further increase in $\mathrm{Ni}(\mathrm{II})$ removal is observed, and thus, $90 \mathrm{~min}$ can be selected as the optimum thermal treatment period at a treatment temperature of $125^{\circ} \mathrm{C}$, at which $60 \% \mathrm{Ni}(\mathrm{II})$ removal is observed.

Variation of the extent of $\mathrm{Ni}(\mathrm{II})$ removal at different treatment temperatures under the optimum conditions of thermal treatment time, shaking time and settling time is shown in Fig. 4b. According to Fig. 4b, the extent of removal of $\mathrm{Ni}(\mathrm{II})$ is generally increased with some fluctuations up to the treatment temperature of $175^{\circ} \mathrm{C}$, at which the maximum efficiency is recorded. The extent of removal is then sharply decreased, and hence, the optimum treatment temperature can be selected as $175^{\circ} \mathrm{C}$ which leads to $71 \%$ removal.

\section{Adsorption kinetics and equilibrium}

The extent of heavy metal removal by peel of Artocarpus nobilis fruit at different contact times was investigated before the equilibrium was reached. These data were then used to check the validity of different kinetics models, as shown in Fig. 5. The amount of biosorption of $\mathrm{Ni}(\mathrm{II})$ at equilibrium $\left(q_{\mathrm{e}}\right)$, determined from the pseudo-first-order model, is $2259 \mathrm{mg} \mathrm{kg}^{-1}$, which is in agreement with the experimental value of $2348 \mathrm{mg} \mathrm{kg}^{-1}$. Similar agreement has been reported in kinetics experiments of orange peel (Feng et al. 2011). Moreover, the regression coefficients of the pseudofirst-order and the pseudo-second-order models are 0.996 and 0.932 , respectively, and therefore, the pseudo-first order is a better fit as compared to the pseudo-second-order model. However, a very low $q_{\mathrm{e}}$ value of $55.55 \mathrm{mg} \mathrm{kg}^{-1}$ obtained for the pseudo-second-order model is much deviated from the experimental value. In addition, the rate constants of the pseudo-first-order and the pseudo-second-order models are $3.50 \times 10^{-2} \mathrm{~min}^{-1}$ and $5.33 \times 10^{-4} \mathrm{~kg} \mathrm{mg}^{-1} \mathrm{~min}^{-1}$, respectively.

Biosorption data obtained within the concentration range of 10.0 and $1000 \mathrm{mg} \mathrm{L}^{-1} \mathrm{Ni}$ (II) show a better fit with the
Fig. 4 Variation of extent of removal of $\mathrm{Ni}$ (II) with a thermal treatment time by biosorbent prepared at $125^{\circ} \mathrm{C}$ and $\mathbf{b}$ treatment temperature of the biosorbent $(0.100 \mathrm{~g}$ peel, $10.0 \mathrm{mg} \mathrm{L}^{-1}$ of $50.0 \mathrm{~mL}$ solution, 120 min shaking time, 30 min settling time, ambient $\mathrm{pH}$ of 5.9)

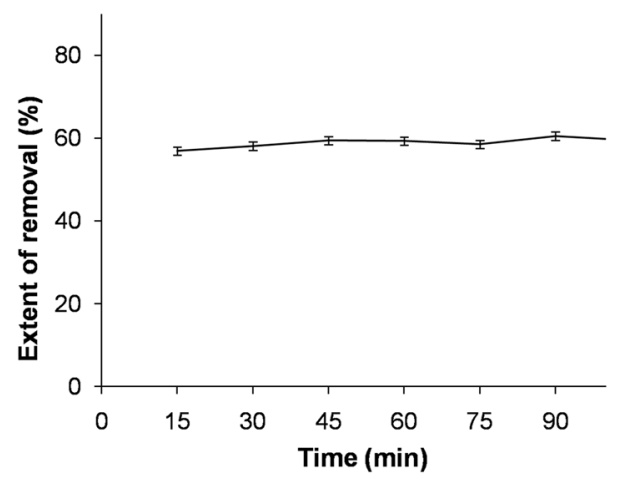

(a)

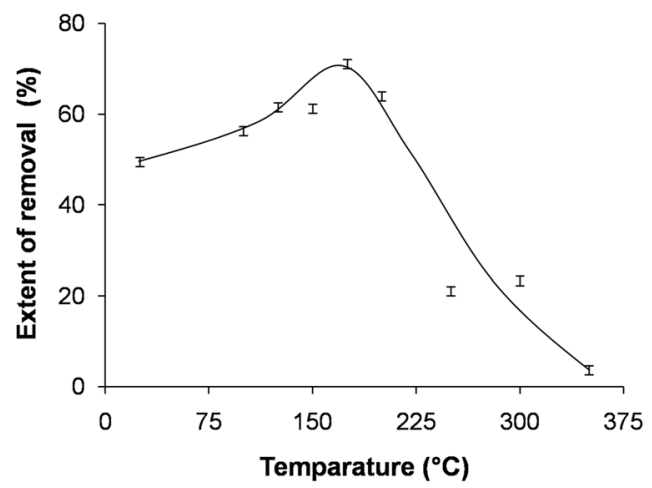

(b) 
Fig. 5 Plots of kinetics models for removal of $\mathrm{Ni}(\mathrm{II})$ from peel of Artocarpus nobilis fruit a Pseudo-first order, b Pseudosecond order $[500.0 \mathrm{~mL}$ of $10.0 \mathrm{mg} \mathrm{L}^{-1} \mathrm{Ni}$ (II) solution, $1.000 \mathrm{~g}$ of fruit peel]

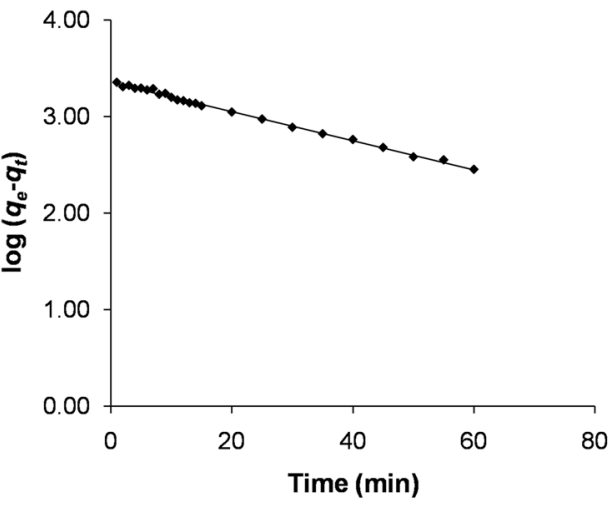

(a)

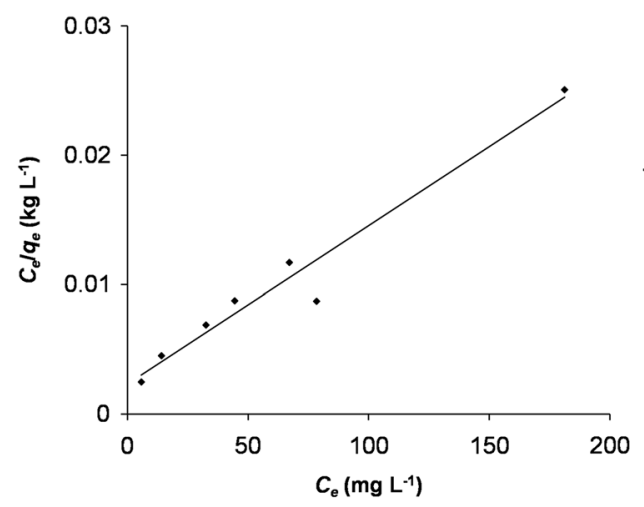

(a)

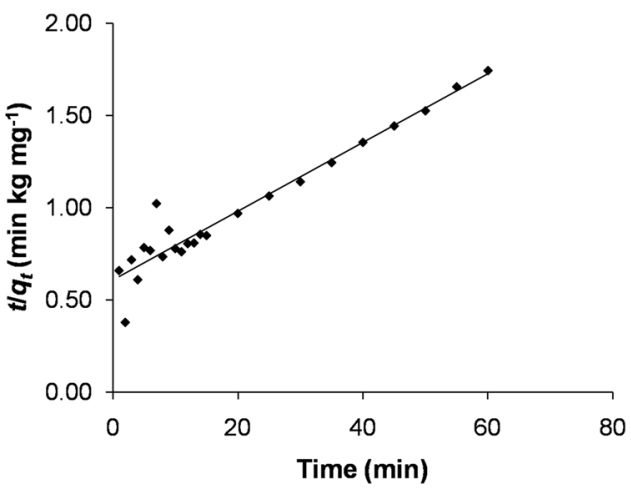

(b)

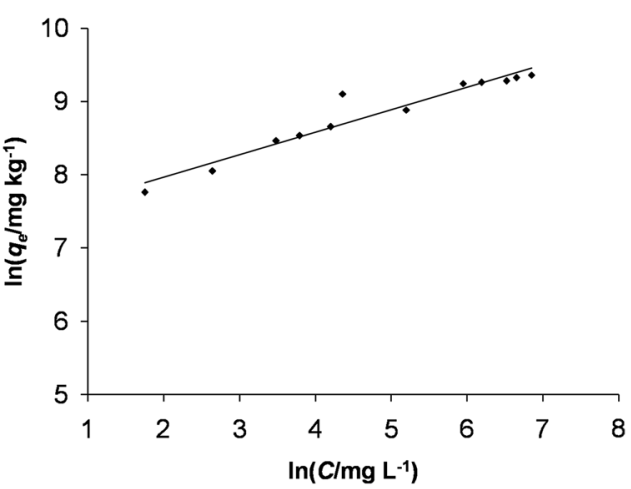

(b) linearized Langmuir isotherm model having a regression coefficient of 0.994 as compared to 0.927 obtained from the Freundlich isotherm model (Fig. 6), indicating the validity of the Langmuir model which shows a maximum adsorption capacity of $12,048 \mathrm{mg} \mathrm{kg}^{-1}$. In addition, the Langmuir isotherm constant $(b)$, the Freundlich isotherm constant $\left(k_{\mathrm{f}}\right)$ and the adsorption intensity $(n)$ were calculated as $1.76 \times 10^{-2} \mathrm{~L} \mathrm{mg}^{-1}, 1559 \mathrm{mg} \mathrm{kg}^{-1}$ and 3.26 , respectively.

\section{Column experiments for removal of $\mathrm{Ni}(\mathrm{II})$}

Column experiments are generally conducted to determine the relationship between adsorbent and adsorbate by varying their amounts at equilibrium as a function of time. Metal ion removal by fixed bed columns can be used for prediction of characteristic breakthrough curves considering the mass transfer limitations revealed by mathematical models and the breakthrough curves representing a ratio of the effluent and influent metal ion concentrations as a function of time (Borba et al. 2006).

\section{Optimization of flow rate}

Breakthrough characteristics for the removal of $\mathrm{Ni}(\mathrm{II})$, monitored by investigating the relative concentration of $\mathrm{Ni}$ (II) in the eluent as a function of effluent volume $\left(V_{\text {eff }}\right)$ at a flow rate of $16.0 \mathrm{~mL} \mathrm{~min}^{-1}$, is shown in Fig. 7. Similar shapes for breakthrough curves were obtained for other flow rates ranging from 4.8 to $16.0 \mathrm{~mL} \mathrm{~min}^{-1}$ as well. The common

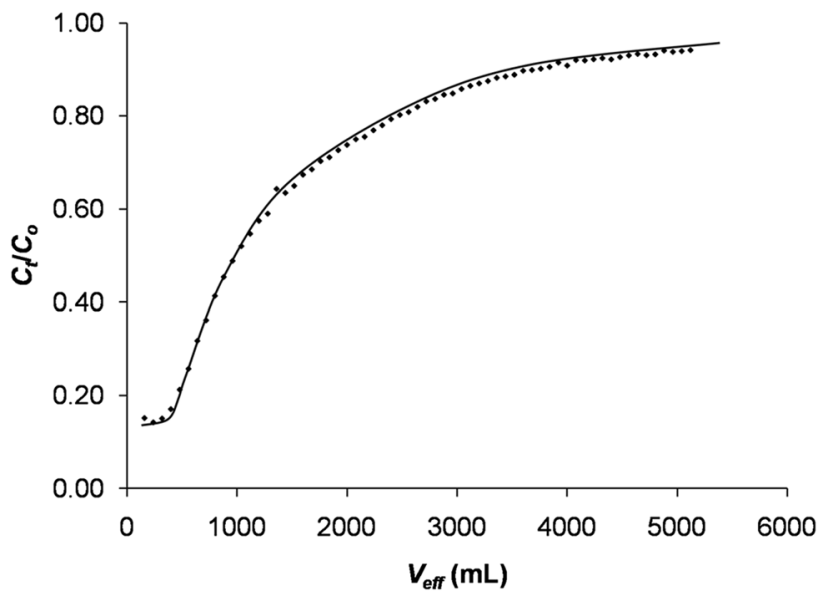

Fig. 7 Breakthrough curve of $C_{\mathrm{t}} / C_{\mathrm{o}}$ versus $V_{\text {eff }}$ of removal of $\mathrm{Ni}(\mathrm{II})$ with peel of Artocarpus nobilis fruit [Ni(II) concentration $10.0 \mathrm{mg}$ $\mathrm{L}^{-1}$, flow rate $16.0 \mathrm{~mL} \mathrm{~min}{ }^{-1}$, biosorbent mass $3.000 \mathrm{~g}$, column height $10.0 \mathrm{~cm}$, internal diameter of column $1.0 \mathrm{~cm}$, sampling frequency $5 \mathrm{~min}$ ] 
Fig. 8 Fitting of Ni(II) removal data for linearized dynamic adsorption models. a Thomas model, b Adams-Bohart model, c Yoon-Nelson model [Flow rate $16.0 \mathrm{~mL} \mathrm{~min}^{-1}$, bed height $10.0 \mathrm{~cm}$, influent $\mathrm{Ni}(\mathrm{II})$ concentration $10.0 \mathrm{mg} \mathrm{L}^{-1}$ ]
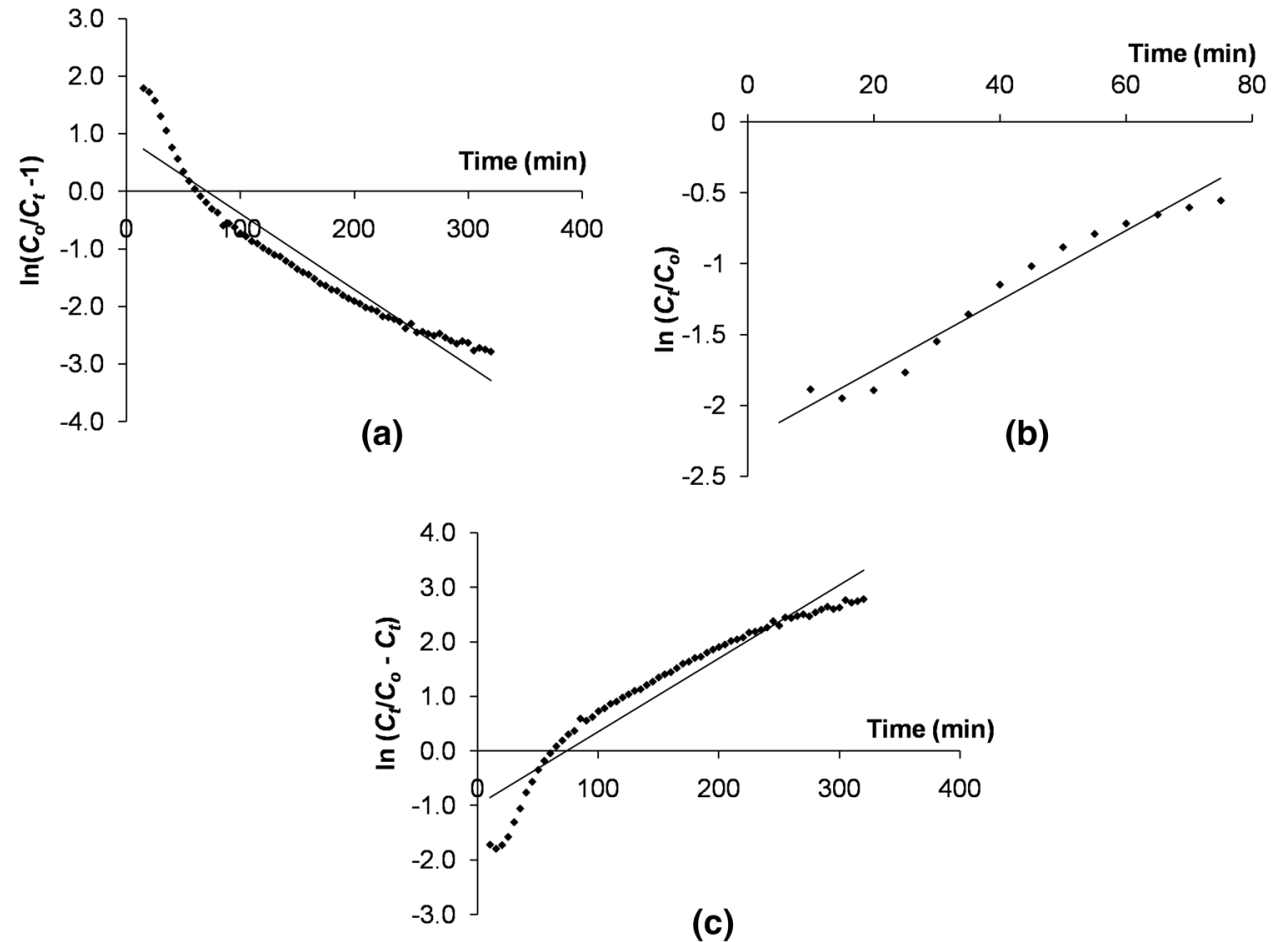

(c) feature to all breakthrough curves is that they show asymmetric profile, leveling off after a long time period.

When the flow rates were increased from 4.8 to $16.0 \mathrm{~mL} \mathrm{~min}^{-1}$, removal percentages decreased as 97,92 , 93,83 and $74 \%$, respectively. Therefore, the flow rate of $8.4 \mathrm{~mL} \mathrm{~min}^{-1}$ was selected as the optimum by considering the maximum efficiency with less time consumption. The extent of removal of $\mathrm{Ni}(\mathrm{II})$ in each flow rate, applied to linearized dynamic adsorption models, namely Thomas, Adams-Bohart and Yoon-Nelson, is shown in Figure 8, and relevant constants are shown in Table 3.

None of the models has shown a good agreement according to regression coefficients. However, the values of Thomas rate constant $\left(K_{\mathrm{th}}\right)$ increased with fluctuations from 1.142 to $1.262 \mathrm{~mL} \mathrm{mg}^{-1} \mathrm{~min}^{-1}$, while equilibrium uptake per gram of the adsorbent $\left(q_{\mathrm{o}}\right)$ was generally decreased from 5.46 to $3.92 \mathrm{mg} \mathrm{g}^{-1}$ with increasing flow rates. Biosorption of Congo red on rice husk, methylene blue on phoenix tree powder and phenol on activated sludge has shown that $q_{\mathrm{o}}$ decreased while Thomas rate constants increased with increasing flow rates supporting the findings of this research (Han et al. 2009; Aksu and Gönen 2004). The rate constant $\left(k_{\mathrm{AB}}\right)$ of the Adams-Bohart model decreases with increasing flow rates, and the saturation concentration $\left(N_{\mathrm{o}}\right)$ increases with increasing flow rates. The rate constant of the Yoon-Nelson model $\left(k_{\mathrm{YN}}\right)$ slightly fluctuates and the time required for $50 \%$ adsorbate breakthrough $(\tau)$ decreases with increasing flow rates. The same phenomenon observed for both model and experimental parameters obtained for the time required for 50\% adsorbate breakthrough. These parameters will be valuable in designing treatment systems for large-scale removal of $\mathrm{Ni}$ (II) from contaminated water or industrial effluents.

\section{Optimization of bed height}

Extent of removal investigated by passing $\mathrm{Ni}(\mathrm{II})$ solution of $10.0 \mathrm{mg} \mathrm{L}^{-1}$ through biosorbent-packed columns with different bed heights of $2.5,5.0,7.5$ and $10.0 \mathrm{~cm}$ shows that removal percentages increase from 43 to $93 \%$ with an increase in bed height. The parameters obtained from different bed heights are shown in Table 4.

The rate constant $\left(k_{\mathrm{AB}}\right)$ determined from the Adams-Bohart model increases while the saturation concentration $\left(N_{\mathrm{o}}\right)$ decreases with an increase in the bed height from 0.94 to $3.53 \mathrm{~L} \mathrm{mg}^{-1} \mathrm{~min}^{-1}$. The rate constants determined from the Yoon-Nelson model $\left(k_{\mathrm{YN}}\right)$ fluctuate between $1.02 \times 10^{-2}$ and $1.21 \times 10^{-2} \mathrm{~min}^{-1}$, and the $\tau$ values are similar to the experimental values of the model. In liquid-solid adsorption, adsorption process follows four basic steps: liquid-phase mass transfer, film diffusion, intra-particle mass transfer and adsorption-desorption reactions (Xu et al. 2013; Crittenden et al. 1986). During the adsorption/biosorption process, a film of the adsorbate creates on the surface of the adsorbent/biosorbent acting as an adsorption barrier for metal ions. Therefore, increase in the bed height would increase film thickness/resistance around the biosorbent. Consequently, sorption process decreases requiring more 
Table 3 Parameters determined from linearized dynamic models at different flow rates

\begin{tabular}{|c|c|c|c|c|c|c|c|c|c|c|}
\hline \multirow{2}{*}{$\begin{array}{l}\text { Flow rate } \\
\left(\mathrm{mL} \min ^{-1}\right)\end{array}$} & \multicolumn{3}{|c|}{ Thomas Model } & \multicolumn{3}{|c|}{ Adams-Bohart Model } & \multicolumn{4}{|c|}{ Yoon-Nelson Model } \\
\hline & $\begin{array}{l}K_{\mathrm{th}} \\
\left(\mathrm{mL} \mathrm{mg}^{-1}\right. \\
\left.\min ^{-1}\right)\end{array}$ & $q_{\mathrm{o}}\left(\mathrm{mg} \mathrm{g}^{-1}\right)$ & $R^{2}$ & $\begin{array}{l}k_{\mathrm{AB}} \times 10^{-3}(\mathrm{~L} \\
\left.\mathrm{mg}^{-1} \min ^{-1}\right)\end{array}$ & $N_{\mathrm{o}}\left(\mathrm{mg} \mathrm{L}^{-1}\right)$ & $R^{2}$ & $\begin{array}{l}k_{\mathrm{YN}} \times 10^{-2} \\
\left(\mathrm{~min}^{-1}\right)\end{array}$ & $\tau(\min )($ Model $)$ & $\tau(\min )(\operatorname{Exp})$ & $R^{2}$ \\
\hline 4.8 & 1.142 & 5.46 & 0.814 & 4.59 & 1069 & 0.983 & 1.76 & 227 & 283 & 0.814 \\
\hline 6.6 & 1.552 & 3.75 & 0.921 & 2.60 & 1174 & 0.972 & 1.55 & 177 & 167 & 0.930 \\
\hline 8.4 & 1.292 & 4.19 & 0.903 & 3.39 & 1363 & 0.969 & 1.50 & 172 & 144 & 0.909 \\
\hline 12.0 & 1.078 & 4.73 & 0.903 & 2.55 & 1661 & 0.974 & 1.48 & 115 & 99 & 0.951 \\
\hline 16.0 & 1.262 & 3.92 & 0.914 & 2.33 & 1960 & 0.959 & 1.34 & 76 & 61 & 0.914 \\
\hline
\end{tabular}

Table 4 Parameters of different dynamic models at different bed heights

\begin{tabular}{llllll}
\hline Model & Column height $(\mathrm{cm})$ & & & \\
\cline { 2 - 6 } & Parameter & 2.5 & 5.0 & 7.5 & 10.0 \\
\hline Thomas model & $R^{2}$ & 0.917 & 0.910 & 0.918 & 0.899 \\
& $K_{\mathrm{th}}\left(\mathrm{mL} \mathrm{mg}^{-1} \mathrm{~min}^{-1}\right)$ & 1.647 & 1.156 & 1.100 & 1.302 \\
Adams-Bohart model & $q_{\mathrm{o}}\left(\mathrm{mg} \mathrm{g}^{-1}\right)$ & 0.456 & 4.626 & 4.563 & 5.08 \\
& $R^{2}$ & 0.819 & 0.929 & 0.967 & 0.974 \\
& $k_{\mathrm{AB}}\left(\mathrm{L} \mathrm{mg}^{-1} \mathrm{~min}^{-1}\right) \times 10^{-3}$ & 0.940 & 1.730 & 2.000 & 3.530 \\
Yoon-Nelson model & $N_{\mathrm{o}}\left(\mathrm{mg} \mathrm{L}^{-1}\right)$ & 4199 & 2622 & 1564 & 1343 \\
& $R^{2}$ & 0.848 & 0.912 & 0.919 & 0.961 \\
& $k_{\mathrm{YN}}\left(\mathrm{min}^{-1}\right) \times 10^{-2}$ & 1.06 & 1.21 & 1.12 & 1.05 \\
& $\tau(\mathrm{Model}),(\mathrm{min})$ & 1 & 76 & 123 & 147 \\
& $\tau($ Exp $),(\mathrm{min})$ & 5 & 71 & 93 & 144 \\
& & 45 & 77 & 83 & 93 \\
\hline
\end{tabular}

time to complete the biosorption process. However, the equilibrium uptake per gram of the adsorbent $\left(q_{\mathrm{o}}\right)$ is increased while the saturation concentration $\left(N_{\mathrm{o}}\right)$ determined from the Adams-Bohart model is decreased.

According to Table 4, Thomas rate constant $\left(K_{\mathrm{th}}\right)$ decreases with an increase in bed height, while equilibrium uptake per gram of the adsorbent $\left(q_{\mathrm{o}}\right)$ increases with an increase in bed height. The saturation concentration $\left(N_{\mathrm{o}}\right)$ decreases with an increase in bed height, while $k_{\mathrm{AB}}$ increases with an increase in bed height. However, the rate constant of the Yoon-Nelson model $\left(k_{\mathrm{YN}}\right)$ was not considerably changed.

\section{Conclusion}

Fruit peel of Artocarpus nobilis, a plant endemic to Sri Lanka, is proven to be an effective low-cost biosorbent for Ni(II). Carboxylic acid and its derivatives are the main functional groups present in the biosorbent as structural materials in cell walls to enhance the metal removal efficiency. Further, the negative charge of the biosorbent is an advantage for $\mathrm{Ni}$ (II) removal ability. Both these aspects contribute to a high adsorption capacity of $12,048 \mathrm{mg} \mathrm{kg}^{-1}$. Under static conditions, the maximum efficiency of $\mathrm{Ni}$ (II) removal reaches $71 \%$ at ambient $\mathrm{pH}$ level when experimental conditions are optimized. Further, removal efficiency of $\mathrm{Ni}$ (II) from synthetic solution is increased up to $93 \%$ under dynamic conditions at the optimum values of $10.0 \mathrm{~cm}$ for bed height and $8.4 \mathrm{~mL} \mathrm{~min}^{-1}$ for flow rate. Regression coefficients of dynamic model application show better agreement with the linearized relationship, demonstrating the validity of the results. These results suggest that the peel of Artocarpus nobilis is highly recommended for large-scale removal of $\mathrm{Ni}(\mathrm{II})$ from wastewater contaminated with $\mathrm{Ni}(\mathrm{II})$.

Open Access This article is distributed under the terms of the Creative Commons Attribution 4.0 International License (http://creativeco mmons.org/licenses/by/4.0/), which permits unrestricted use, distribution, and reproduction in any medium, provided you give appropriate credit to the original author(s) and the source, provide a link to the Creative Commons license, and indicate if changes were made.

\section{References}

Abu Bakar MF, Mohamed M, Rahmat A, Fry J (2009) Phytochemicals and antioxidant activity of different parts of 
bambangan (Mangifera pajang) and tarap (Artocarpus odoratissimus). Food Chem 113:479-483. https://doi.org/10.1016/j.foodc hem.2008.07.081

Aksu Z, Gönen F (2004) Biosorption of phenol by immobilized activated sludge in a continuous packed bed: prediction of breakthrough curves. Process Biochem 39:599-613. https://doi. org/10.1016/S0032-9592(03)00132-8

Al-Asheh S, Banat F, Al-Omari R, Duvnjak Z (2000) Predictions of binary sorption isotherms for the sorption of heavy metals by pine bark using single isotherm data. Chemosphere 41:659-665. https ://doi.org/10.1016/S0045-6535(99)00497-X

Ali AH (2013) Comparative study on removal of cadmium(II) from simulated wastewater by adsorption onto GAC, DB, and PR. Desalin Water Treat 51:5547-5558. https://doi.org/10.1080/19443 994.2013.769927

Alomá I, Martín-Lara MA, Rodríguez IL, Blázquez G, Calero M (2012) Removal of nickel(II) ions from aqueous solutions by biosorption on sugarcane bagasse. J Taiwan Inst Chem Eng 43:275-281. https ://doi.org/10.1016/j.jtice.2011.10.011

Amuda OS, Ibrahim AO (2006) Industrial wastewater treatment using natural material as adsorbent. Afr J Biotechnol 5:1483-1487

Ayoob S, Gupta AK (2007) Sorptive response profile of an adsorbent in the defluoridation of drinking water. Chem Eng J 133:273-281. https://doi.org/10.1016/j.cej.2007.02.013

Aziz ASA, Manaf LA, Man HC, Kumar NS (2014) Column dynamic studies and breakthrough curve analysis for $\mathrm{Cd}(\mathrm{II})$ and $\mathrm{Cu}(\mathrm{II})$ ions adsorption onto palm oil boiler mill fly ash (POFA). Environ Sci Pollut Res 21:7996-8005. https://doi.org/10.1007/s1135 6-014-2739-5

Baral SS, Das N, Ramulu TS, Sahoo SK, Das SN, Chaudhury GR (2009) Removal of $\mathrm{Cr}$ (VI) by thermally activated weed Salvinia cucullata in a fixed-bed column. J Hazard Mater 161:1427-1435. https://doi.org/10.1016/j.jhazmat.2008.04.127

Belhachemi M, Addoun F (2011) Comparative adsorption isotherms and modeling of methylene blue onto activated carbons. Appl Water Sci 1:111-117. https://doi.org/10.1007/s13201-011-0014-1

Bhatnagar A, Minocha AK (2010) Biosorption optimization of nickel removal from water using Punica granatum peel waste. Colloids Surfaces B Biointerfaces 76:544-548. https://doi.org/10.1016/j. colsurfb.2009.12.016

Borba CE, Guirardello R, Silva EA, Veit MT, Tavares CRG (2006) Removal of nickel(II) ions from aqueous solution by biosorption in a fixed bed column: experimental and theoretical breakthrough curves. Biochem Eng J 30:184-191. https://doi.org/10.1016/j. bej.2006.04.001

Castro RSD, Caetano L, Ferreira G, Padilha PM, Saeki MJ, Zara LF, Martines MAU, Castro GR (2011) Banana peel applied to the solid phase extraction of copper and lead from river water: preconcentration of metal ions with a fruit waste. Ind Eng Chem Res 50:3446-3451. https://doi.org/10.1021/ie101499e

Chu KH (2010) Fixed bed sorption: setting the record straight on the Bohart-Adams and Thomas models. J Hazard Mater 177:10061012. https://doi.org/10.1016/j.jhazmat.2010.01.019

Crittenden JC, Hutzler NJ, Geyer DG, Oravitz JL, Friedman G (1986) Transport of organic compounds with saturated groundwater flow: model development and parameter sensitivity. Water Resour Res 22:271-284. https://doi.org/10.1029/WR022i003p00271

Demirbas A (2008) Heavy metal adsorption onto agro-based waste materials: a review. J Hazard Mater 157:220-229. https://doi. org/10.1016/j.jhazmat.2008.01.024

Feng N, Guo X, Liang S, Zhu Y, Liu J (2011) Biosorption of heavy metals from aqueous solutions by chemically modified orange peel. J Hazard Mater 185:49-54. https://doi.org/10.1016/j.jhazm at.2010.08.114

Fiol N, Villaescusa I, Martínez M, Miralles N, Poch J, Serarols $\mathrm{J}$ (2006) Sorption of $\mathrm{Pb}(\mathrm{II}), \mathrm{Ni}(\mathrm{II}), \mathrm{Cu}(\mathrm{II})$ and $\mathrm{Cd}(\mathrm{II})$ from aqueous solution by olive stone waste. Sep Purif Technol 50:132-140. https://doi.org/10.1016/j.seppur.2005.11.016

Han R, Wang Y, Zhao X, Wang Y, Xie F, Cheng J, Tang M (2009) Adsorption of methylene blue by phoenix tree leaf powder in a fixed-bed column: experiments and prediction of breakthrough curves. Desalination 245:284-297. https://doi.org/10.1016/j. desal.2008.07.013

Hanif M, Nadeem R, Zafar M, Akhtar K, Bhatti H (2007) Kinetic studies for $\mathrm{Ni}(\mathrm{II})$ biosorption from industrial wastewater by Cassia fistula (Golden Shower) biomass. J Hazard Mater 145:501-505. https://doi.org/10.1016/j.jhazmat.2007.01.022

Hossain MA, Ngo HH, Guo WS, Nghiem LD, Hai FI, Vigneswaran S, Nguyen TV (2014) Competitive adsorption of metals on cabbage waste from multi-metal solutions. Bioresour Technol 160:79-88. https://doi.org/10.1016/j.biortech.2013.12.107

Iqbal M, Saeed A, Zafar SI (2009) FTIR spectrophotometry, kinetics and adsorption isotherms modeling, ion exchange, and EDX analysis for understanding the mechanism of $\mathrm{Cd}^{2+}$ and $\mathrm{Pb}^{2+}$ removal by mango peel waste. J Hazard Mater 164:161-171. https://doi.org/10.1016/j.jhazmat.2008.07.141

Jagtap UB, Bapat VA (2010) Artocarpus: a review of its traditional uses, phytochemistry and pharmacology. J Ethnopharmacol 129:142-166. https://doi.org/10.1016/j.jep.2010.03.031

Lim LBL, Priyantha N, Hei Ing C, Khairud Dahri M, Tennakoon DTB, Zehra T, Suklueng M (2013) Artocarpus odoratissimus skin as a potential low-cost biosorbent for the removal of methylene blue and methyl violet 2B. Desalin Water Treat 53:964975. https://doi.org/10.1080/19443994.2013.852136

Lim LBL, Priyantha N, Mansor NHM (2015) Artocarpus altilis (breadfruit) skin as a potential low-cost biosorbent for the removal of crystal violet dye: equilibrium, thermodynamics and kinetics studies. Environ Earth Sci 73:3239-3247. https:// doi.org/10.1007/s12665-014-3616-8

Lim LBL, Priyantha N, Chieng HI, Dahri MK (2016) Artocarpus camansi Blanco (Breadnut) core as low-cost adsorbent for the removal of methylene blue: equilibrium, thermodynamics, and kinetics studies. Desalin Water Treat 57:5673-5685. https://doi. org/10.1080/19443994.2015.1007088

McKendry P (2002) Energy production from biomass (part 1): overview of biomass. Bioresour Technol 83:37-46. https://doi. org/10.1016/S0960-8524(01)00118-3

Olalekan AP, Dada AO, Okewale AO (2013) Comparative adsorption isotherm study of the removal of $\mathrm{Pb}^{2+}$ and $\mathrm{Zn}^{2+}$ onto agricultural waste. Res J Chem Environ Sci 1:22-27

Özer A, Gürbüz G, Çalimli A, Körbahti BK (2008) Investigation of nickel(II) biosorption on Enteromorpha prolifera: optimization using response surface analysis. J Hazard Mater 152:778-788. https://doi.org/10.1016/j.jhazmat.2007.07.088

Pavan FA, Lima IS, Lima EC, Airoldi C, Gushikem Y (2006) Use of Ponkan mandarin peels as biosorbent for toxic metals uptake from aqueous solutions. J Hazard Mater 137:527-533. https:// doi.org/10.1016/j.jhazmat.2006.02.025

Persson I (2010) Hydrated metal ions in aqueous solution: How regular are their structures? Pure Appl Chem 82:1901-1917. https:// doi.org/10.1351/PAC-CON-09-10-22

Priyantha N, Lim LBL, Dahri MKD, Tennakoon DTB (2013) Dragonfruit skin as a potential low-cost biosorbent for the removal of manganese(II) ions. J Appl Sci Environ Sanit 8(3):179-188

Qaiser S, Saleemi AR, Umar M (2009) Biosorption of lead from aqueous solution by Ficus religiosa leaves: batch and column study. J Hazard Mater 166:998-1005. https://doi.org/10.1016/j.jhazm at.2008.12.003

Rashid A, Bhatti HN, Iqbal M, Noreen S (2016) Fungal biomass composite with bentonite efficiency for nickel and zinc adsorption: a mechanistic study. Ecol Eng 91:459-471. https://doi. org/10.1016/j.ecoleng.2016.03.014 
Reddy DHK, Seshaiah K, Reddy AVR, Lee SM (2012) Optimization of $\mathrm{Cd}(\mathrm{II}), \mathrm{Cu}(\mathrm{II})$ and $\mathrm{Ni}(\mathrm{II})$ biosorption by chemically modified Moringa oleifera leaves powder. Carbohydr Polym 88:1077-1086. https://doi.org/10.1016/j.carbpol.2012.01.073

Salamatinia B, Kamaruddin AH, Abdullah AZ (2008) Modeling of the continuous copper and zinc removal by sorption onto sodium hydroxide-modified oil palm frond in a fixed-bed column. Chem Eng J 145:259-266. https://doi.org/10.1016/j.cej.2008.04.025

Shahmohammadi-Kalalagh S, Babazadeh H (2014) Isotherms for the sorption of zinc and copper onto kaolinite: comparison of various error functions. Int J Environ Sci Technol 11:111-118. https://doi. org/10.1007/s13762-013-0260-x

Shroff KA, Vaidya VK (2011) Kinetics and equilibrium studies on biosorption of nickel from aqueous solution by dead fungal biomass of Mucor hiemalis. Chem Eng J 171:1234-1245. https://doi. org/10.1016/j.cej.2011.05.034

Sud D, Mahajan G, Kaur MP (2008) Agricultural waste material as potential adsorbent for sequestering heavy metal ions from aqueous solutions-a review. Bioresour Technol 99:6017-6027. https ://doi.org/10.1016/j.biortech.2007.11.064

Tamilselvi S, Asaithambi M (2015) Column mode adsorption studies of acid dye using a novel adsorbent. Rasayan J Chem 8:84-91
Tosun İ (2012) Ammonium removal from aqueous solutions by clinoptilolite: determination of isotherm and thermodynamic parameters and comparison of kinetics by the double exponential model and conventional kinetic models. Int J Environ Res Public Health 9:970-984. https://doi.org/10.3390/ijerph9030970

Witek-Krowiak A, Szafran RG, Modelski S (2011) Biosorption of heavy metals from aqueous solutions onto peanut shell as a low-cost biosorbent. Desalination 265:126-134. https://doi. org/10.1016/j.desal.2010.07.042

Xu Z, Cai J, Pan B (2013) Mathematically modeling fixed-bed adsorption in aqueous systems. J Zhejiang Univ Sci A 14:155-176. https ://doi.org/10.1631/jzus.A1300029

Zafar MN, Nadeem R, Hanif MA (2007) Biosorption of nickel from protonated rice bran. J Hazard Mater 143:478-485. https://doi. org/10.1016/j.jhazmat.2007.03.042

Publisher's Note Springer Nature remains neutral with regard to jurisdictional claims in published maps and institutional affiliations. 